\title{
Олфакторен невробластом (Случай от практиката)
}

\author{
Г. Бояджиев \\ Лайф Хоспитал - Бургас
}

\section{Summary}

Olfactory neuroblastoma is rare tumor of nasal cavity and sinuses. A case of 68 old woman with olfactory neuroblastoma localized only in nasal cavity, successfully threated only by FESS is presented.

\section{Резюме}

Олфакторният невробластом е рядко срещано туморно заболяване на носа и околоносните кухини. Представя се случай от практиката на жена на 68 години с олфакторен невробластом, локализиран само в носната кухина, успешно третиран чрез ендоскопична синусна хирургия.
$\mathrm{O}$ лфакторният невробластом е рядко срещано туморно заболяване на носа и околоносните кухини. Познато е и под наименованието естезионевробластом. Произхожда от невроепитела на олфакторния орган, който както се знае, заема най-горната част на носната кухина - горна носна конха, срещуположната част на септума, lamina cribrosa. Олфакторният епител съдаржа три вида клетки -базални, опорни и сетивни, които могат да бъдат представени в тумора.

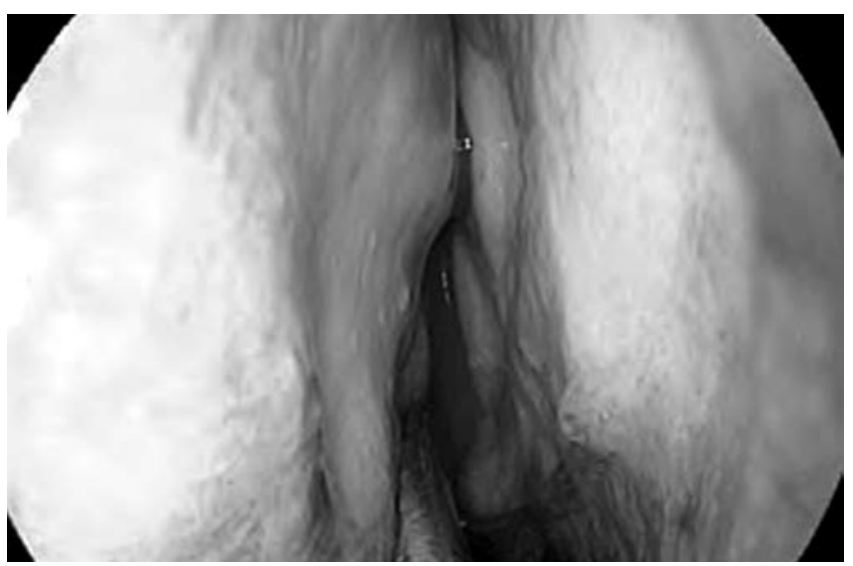

Фиг. 1. Олфракторната зона при ендоскопия се отличава от околната носна лигавица по жълтеникавия си цвят.

Преглеждайки литературата, от 1924 година досега са отчетени 1200 случая по света, като $80 \%$ от тях са диагностицирани през последните 25 години. Няма определена предилекция на тумора по отношение на раса, пол и възраст.

При хистологичното му изследване прави впечатление гнездния характер на тумора, намиращ се под интактна мукоза, разделен от добре васкуларизирана 
фиброзна страма. Клетките са малки, кръгли и сини, малко по-големи от лимфоцитите. В 5\% от случаите обарзуват типични розетки на FlexnerWintersteiner, или псевдорозетки на Homer-Wright, които се срещат в $30 \%$ от случаите.

Туморите се разделят в четири степени в зависимост от диференцияцията клетките, количеството строма, митотичния индекси некрозите, като понякога границата е дискутабилна. В I степен попадат повечето тумори, които се представят с типичните клетки, добре представена васкуларизирана строма, без некрози и митози. В IV степен тумора изглежда анапластичен, с множество митози и некрози.
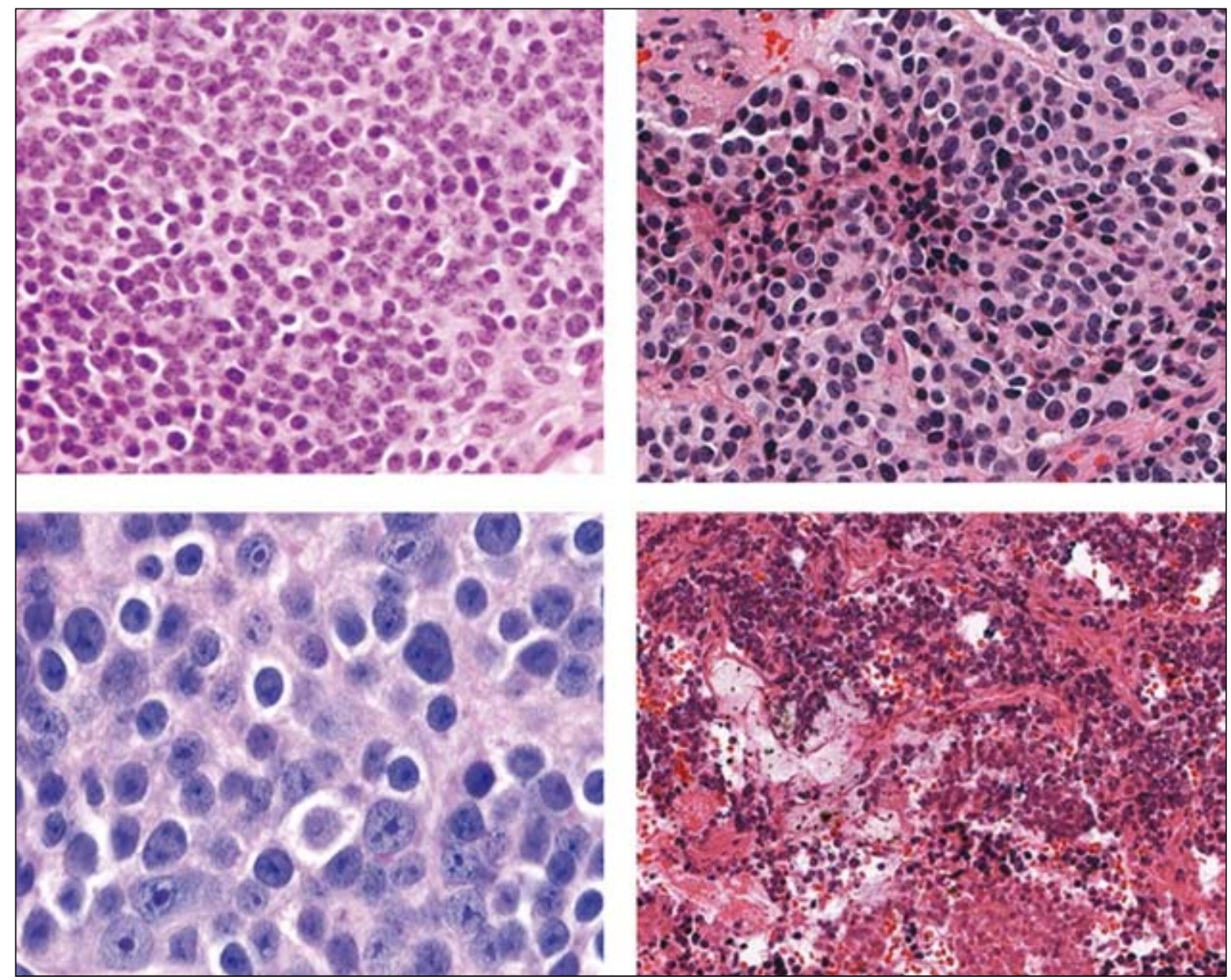

Фиг. 2. Степени на олфакторния невробластом I-IV.

Другата група тумори, от която трябва да се диагностицира естезионевробластома е LEMONS (lymphoma, Ewing sarcoma, melanoma, olfactory/ other [ENBs, rhabdomyosarcoma или Markel cell carcinoma], neuroblastoma, and small cell carcinoma) заради общата патохистологична изява с малки крьгли сини клетки.

Стадирането има много важно значение за изгражданото на лечебна стратегия на лечение. В практиката се срещат няколко класификации:

По Kadish естезионевробластомите се разделят на А тип - заемащи само носната кухина, тип В - с разпространение в параназалните синуси и тип C - c разпространение в мозъка. Morita et al (1993) добавя D тип - с далечно разпространение (метастази).
Според ТNM системата:

Т1 - тумора засяга носната кухина и/или околоносните кухини (без сфеноидалния синус).

Т2 - тумора засяга носната кухина и/или околоносните кухини (със сфеноидалния синус), с ерозия или разрушаване на lamina cribrosa.

Т3 - тумора се разпространява в орбитата или предна черепна ямка, без да засяга дурата.

T4 - тумора засяга мозъка.

N0 - няма шийни метастази.

N1 - всякакви форми на шийни метастази.

М0 - без далечни метастази

M1 - с далечни метастази.

Туморьт има многобройна клинична изява и признаците могат да бъдат групирани в следните групи: 
А) Носни: запушване на носа, кървене, хип- и аносмия. Намирането само на едностранно изявен полип, както е при описания случай, трябва да изостри вниманието на УНГ специалиста, тъй като много често е причинено от:

-Дентална и периодонтална инфекция (обикновено хронична), причиняваща едностранен максиларен синуит, с полипоидна дегенерация на лигавицата; - инвертен папилом -рядко се намира двустранно, често е замаскиран от едностранна полипоза;

- гъбичкова инфекция в носа и околоносните кухини;

-чуждо тяло (ринолит);

- тумор на носната кухина, синусите, предна черепна ямка.

Б) Лицеви - подуване на латералната носна стена, анестезия и парестезия на определен лицев участъК;

В) Неврологични: Главоболие, при напреднали случаи - синдром на увеличено вътречерепно налягане, синдром на патология в предна черепна ямка и т.н.

Г) Очни - парализа, намаление на зрението до липсващо зрение, екзофталм;

Обикновено преминават поне 6 месеца, докато се стигне до поставяне на диагнозата. Най-често е неочаквана находка при пациенти, претърпяващи носна хирургия или като причина за епистаксис. Обективно представлява сиво-червена туморна формация с различна големина, обхващаща горната част на носната кухина, едностранно разположена.

Няма специфични лабораторни методи за диагностицирането. Най-важното е направата на КАТ, на малки срезове с контрастиране, за да се подсилят контурите на формацията и да се прецени разпространението. Насочено да се търси дали е запазена целостта на lamina papyracea, lamina cribrosa и fovea ethmoidalis. Често пъти, блокирайки остиумите на синусите, тумора причинява сателитен синуит. Като в случая бяха засегнати фронталния и максиларния синуси.

Лечение - поради редкостта на тумора има разнообразни мнения за начина на лечение, но преобладават мненията за хирургичната резекция на тумора, с последваща радиотерапия, което се счита за „златен стандарт“ през последните 20 години. Хирургическото лечение зависи от разпространението процеса и може да включва FESS, ендоскопично премахване на тумора (ендоскопична краниофациална резекция (ECFR), така и разширени отворени резекции на базата на предна черепна ямка, за да бъде предпазен, доколкото е възможно, мозъка и очните нерви.
При напреднали тумори може да бъде включена и адювантна химиотерапия. Както и при много други тумори на носа и околоносните кухини, границите на резекцията трудно се проследяват по цялата си дължина, така че е възможно да се намерят участъци в които резекцията не е била онкологично радикална.

В 5-7\% от пациентите имат шийни метастази, които се лекуват с шийна дисекция.

В представения случай става дума за жена на 68 години, която от една година започва да усеща постепенно настъпващо нарушение на носното дишане за лявата ноздра, което в последно време става невъзможно. Свързва оплакванията си с пролежаване в реанимация след направено сърдечно клапно протезиране, където е била поставена назогастрална сонда през същата ноздра. Съответно и е било предписано антикоагулантно лечение. Потьрсила е лекарска помощ поради кървене от лявата ноздра, при което не е диагностицирана туморна формация, а направо е поставена предна носна тампонада. Сметнало се е, че се касае за кървене следствие лечението със синтром.

Пристига с оплаквания от силно затруднено носно дишане вляво и периодични слаби кръвотечения от носа. При направения оглед на носната кухина вляво се вижда голям полип, изхождащ под залавното място на средната носна конха, напълно обструктиращ общия носов ход. Има оскъдно количество слузно-гноен секрет. Болната носи направена преди рентгенография, на която се изявяват данни за пансинуит вляво.

Болната проведе необходимата подготовка за обща анестезия, под която се проведе оперативното лечение. При него след премахване на единичния полип, се видя голяма туморна формация със сиво-червеникав цвят, заловена за свободния ръб на средната носна конха. Оперативното и отстраняване протече при бурно кървене, което престана изведнъж след премахване на целия тумор. Резицира се свободния ръб на средната носна конха. Отвори се максиларния синус през устното предверие и се огледа с оптика. Данни за туморна инвазия не бяха открити. Поради продължаващото кървене се направи задна плюс предна носна тампонада, а малкия вестибуларен разрез се заши.

Следоперативният период протече сравнително гладко, с изключение на това, че двукратните опити за премахване на тампонадата водеха до обилно кървене и едва след 5 дни успяхме да премахнем носната тампонада.

След премахването изпратихме болната на КАТ, при което не се отчетоха данни за тумор в носната кухина, но персистираха данните за пансинуит. 



Фие. 3. КАТ на пациентката след оперативната интервенция. Bcе още персистират данните за пансинуит отляво.

Хистологичното изследване показа данни за невробластом, поради което материала беше изпратен за допълнително имунохистохимично изследване, което потвърди естезионевробластома.

Болната беше представена на Онкокомитет, който препорьча наблюдение на болната.

\section{Литература:}

1. Theilgaard SA, Buchwald C, Ingeholm P. Esthesioneuroblastoma: a Danish demographic study of 40 patients registered between 1978 and 2000. Acta Otolaryngol. Apr 2003; 123(3): 433-9.

2. Kadish S, Goodman M, Wang CC. Olfactory neuroblastoma. A clinical analysis of 17 cases. Cancer. Mar 1976; 37(3): 1571-6.

3. Morita A, Ebersold MJ, Olsen KD, Foote RL, Lewis JE, Quast LM. Esthesioneuroblastoma: prognosis and management. Neurosurgery

4. Esthesioneuroblastoma: Endonasal Endoscopic Treatment; Paolo G. Castelnuovo, M.D., 1 Giovanni Delù, M.D., 1 Federica Sberze, M.D., 1 Andrea Pistochini, M.D., 1 Cristhian Cambria, M.D., 1 Paolo Battaglia, M.D., 1 and Maurizio Bignami, M.D.1Skull Base. 2006 February;
Надявам се, че представения случай на естезионевробластом ще заинтересува практикуващите оториноларинголози поради неговата сравнителна рядкост и предизвикателствата, които представя при неговото лечение.

16(1): 25-30. Prepublished online 2005 December 5. doi: 10.1055/s2005-922097.

5. Evaluation and Management of Antrochoanal Polyps; Huseyin Yaman, Suleyman Yilmaz, Elif Karali, Ender Guclu, and Ozcan Ozturk. Clin Exp Otorhinolaryngol. 2010 June; 3(2): 110-114.

6. Endoscopic Nasal and Anterior Craniotomy Resection for Malignant Nasoethmoid Tumors Involving the Anterior Skull Base. Paolo G. Castelnuovo, Evaristo Belli, Maurizio Bignami, Paolo Battaglia, Federica Sberze, and Giustino Tomei; Skull Base. 2006 February; 16(1): 15-18.

7. Olfactory Neuroblastoma. Lester D. R. Thompson; Head Neck Pathol. 2009 September; 3(3): 252-259. 